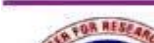 \\ APA SPCRD GLOBAL PUBLISHING \\ Sustainable Solutions Review of Applied Management
and Social Sciences \\ Journal homepage: http://ramss.sperd.org

\section{Good Governance via E-Governance: Moving towards Digitalization for a Digital Economy}

a Sarfraz Batool, ${ }^{\text {b }}$ Shahzad Ali Gill, c Saba Javaid, ${ }^{\text {d }}$ Ali Junaid Khan

${ }^{a}$ Assistant Professor, Department of Political Science, The Islamia University of Bahawalpur, Pakistan Email: Sarfraz.batool@iub.edu.pk

${ }^{\mathrm{b}}$ Assistant Professor, Department of Public Administration, The Islamia University of Bahawalpur, Pakistan Email: Shahzadaligill@gmail.com

c Institute of Business, Management \& Administrative Sciences, The Islamia University of Bahawalpur, Pakistan Email: Sabashahzadali@gmail.com

${ }^{\mathrm{d}}$ Institute of Business, Management \& Administrative Sciences, The Islamia University of Bahawalpur, Pakistan

Email: Junaaidkhan@yahoo.com

\begin{tabular}{l}
\hline ARTICLE DETAILS \\
\hline History: \\
Accepted 20 December 2021 \\
Available Online December 2021
\end{tabular}

\section{Keywords:}

E-governance, E-government, Good Governance, Pakistan, Citizen, Digital Pakistan

\section{JEL Classification:}

G34, G39

DOI: $10.47067 /$ ramss.v4i4.186

\section{ABSTRACT}

E-governance has become a well-celebrated trend in developed countries for the last three decades. It is considered an effective instrument to ensure good governance practices in any state. According to the digital state survey, the USA ranked highly in e-governance delivery, Europe ranked second, and Asia ranked third in e-governance among all other regional entities. However, this survey ranked countries on social measures such as e-democracy, e-commerce, erevenue, e-taxation, etc. Information and communication technology (ICT) has brought a revolutionary change in the performance of governments all over the world. Governments are using ICT for multiple purposes, i.e., they use Government to Employee technology (G2E) to make their communication and correspondence efficient with their employees; they use Government to Government technology $\left(G_{2} G\right)$ to make their record-keeping procedures smooth and efficient; and they use Government to Business (G2B) and Business to Government (B2G) technology to create ease in doing business and attract local and foreign investors for economic development. Governments use governmentto-citizen technology $\left(\mathrm{G}_{2} \mathrm{C}\right)$ to make service delivery more efficient, responsive, and end-user-friendly. However, for a long time, governments remained reactive to e-governance strategies, but this trend has changed. Now, they are proactive in adopting the e-governance model to ensure better social indicators and a corruption-free society. This study used the descriptive approach to describe the various initiatives undertaken by the current government to enhance the service delivery of the public sector. Therefore, this study has several implications for policymakers wishing to analyze the output of technological initiatives undertaken for good governance.

(C) 2021 The authors. Published by SPCRD Global Publishing. This is an open-access article under the Creative Commons Attribution-

NonCommercial 4.0 


\section{Introduction}

In this era of the internet generation, the use of information and communication technology (ICT) has greatly increased. This growth has resulted in the emergence of a knowledge-based society that provides various facilities (for the public) to perform certain activities and processes in a much more transparent, efficient, and smooth manner. The advancement of ICT and the unification of the electronic media and resources in the services sector helped to promote a knowledge-based society on a large scale. Therefore, today, electronic media are being used in almost every field in the world, and concepts like e-governance, e-government, e-education, e-payments, e-transfer, etc. have emerged in global society. Governments benefited from these electronic media as well, allowing them to carry out their activities and processes in a more efficient and transparent manner. So, concepts like e-government and e-governance have emerged and are being utilized to enhance the effectiveness and efficiency of government processes and functions. Because the terms "government" and "governance" are both related and work to provide facilities to the common public, these terms are often used interchangeably.

E-governance and e-government are often used interchangeably, and many people consider them to be the same concept, but in reality, these two terms are quite different from each other. The concept of e-government is related to the functioning and processes of the government by implementing ICT. The use of electronic media provides great benefits, like governments adopting electronic media to perform their duties to improve their performance. It ensures transparency and efficiency in various operations. It provides easy access to information for the common public and increases communication between the people and governments. Further, it also ensures the increased participation of the citizens in various government operations. Therefore, the quality of public service is also ensured.

In contrast, e-governance is related to utilizing ICT to provide government services to the people, disseminate information, and communicate with the general public. It has benefited from the guidance of the government to make improvements in key areas. Citizens are empowered through easy access to information. Moreover, it also increased the reach of the government to the last beneficiary. So, we can say that e-government is a protocol of one-way communication while egovernance is a protocol of two-way communication (Wikipedia, 2021). So, defining the difference between these two terms is easy now. E-government is basically related to the systems of the government, and e-governance is related to the functions of the government. While e-government implies expanding the reach of government services, many system structures and functions are receiving support and being transformed (Singh, 2017).

The term "e-governance" stands for "electronic governance." It is a new trend in the government and administration sector to provide facilities to the common masses. Izhar-ud-Din (2017) said that "e-governance means the utilization of the internet and World Wide Web (WWW) for the transfer of information and delivery of services from the government to citizens" (Izhar Ud Din \& Xue, 2017). Atta-Ullah (2021) defines the concept of e-governance in these words: "Egovernance stands for electronic governance. It is a unification of information and communication technology (ICT) in all the operations to augment the potential of the government to satisfy the requirements of the local public" (Atta Ullah, 2021). So, "e-governance may be defined as the delivery of government services and information to the public by using electronic means" (Ilyas, 2016). Its main aim is to enhance the efficiency of the government and also increase the level of outreach in different public or private sectors. 
Today, in modern times, it is difficult to imagine the efficiency and outreach of governmental activities on a large scale if the electronic media and ICT were missing from the scene. E-governance is basically aimed at delivering efficient and effective services regarding administration, transparency, and the public sector. Therefore, an efficient setup of e-governance increases the efficiency of government activities. The study of Atta Ullah (2021) recognizes the importance of egovernance in modern times. "E-governance is noteworthy because it minimizes corruption, enhances transparency, increases convenience, increases gross domestic product (GDP) growth, allows a way for citizens to be involved directly with their country, reduces overall costs, and broadens the spread of a government. Through an efficient e-governance system, the government increases the amount and quality of information and services delivered to the local public by using ICT in a simple, economical, and productive way "(Atta Ullah, 2021).

It is now an admitted fact that e-governance has indispensable value to achieving the target of good governance, and it is crucial for the states to understand this fact that more services and ease for the citizens is the basic prerequisite of good governance. It is quite true because the inclusion of e-governance excludes the extra services of middlemen and extra payments. Further, e-governance made many more changes in the administrative setups to play an effective role in the government and public offices. Its significance can be elaborated upon from these words as well:

1. E-governance is actually a revolutionary change for governments to perform their functions with great ease and ensure the outreach of facilities to the public.

2. E-governance simply makes it easy for citizens and businesses to access information.

3. It helps in the decision-making process by giving information about the performance of different services in various departments. In this way, it is also beneficial to chalk out strategies to improve their efficiency.

4. E-governance ensures transparency in decision-making and the public is satisfied due to their desired results/outcomes.

5. E-governance ensures the maximum participation of citizens in the governance structure.

6. The performance and efficiency of the various departments are easy to monitor and measure.

7. The public are satisfied because it reduces their effort and saves their time.

8. E-governance works as a bridge that helps bring citizens and their government close to each other.

9. The public has access to contact government agencies.

10. E-governance reduced the practise of bribery because middlemen were excluded from the scene.

11. E-governance enhances the interactions of state organs, commercial communities, and civil society.

12. It also increased the interaction of each sector of e-governance, which are $\mathrm{G} 2 \mathrm{G}, \mathrm{G} 2 \mathrm{~B}$, and $\mathrm{G} 2 \mathrm{C}$ in transactions, transfers, or payments.

Despite the fact that e-governance has great benefits for the government and the public, there are some issues that persist that hinder the progress of e-governance. Pakistan is a developing country but still aims to develop the e-governance system to improve its status as a digital country, i.e., digital Pakistan. 


\section{Literature Review}

\subsection{The Link between E-Government and Good Governance}

The advancement of ICT has already revolutionized communication patterns, as well as government-to-government relations. In the previous century, the establishment of good governance became a dream of every state because it enhanced the effectiveness and efficiency of public service delivery (Javeria et al., 2013). Therefore, the satisfaction level of the public rises. However, in the twenty-first century, the medium to establish successful good governance in any state is the instalment of the patterns of e-governance in the government and public offices. The applicability of the norms of good governance like decentralization, accountability, efficiency, transparency, administrative reforms, and maximum participation of the public are core issues in recent times. So, the mechanisms of e-governance, due to their fast response and efficiency, grab attention and help to ensure good governance. The UN's second "World Public Sector Report" (2003) anticipated the transformation of the governing patterns due to the advancements in ICT. In this report, egovernment is defined in these words, "E-government is a government that applies ICT to transform its internal and external relationships" (UN, 2003). It further narrates that the application of ICT to government operations can raise society's expectations about government performance to a much higher level, but it cannot alter the functions and obligations of the government to maintain legitimacy, transparency, and accountability.

Saidi and Yared (2002) also endorsed the point of view that "e-governance is a major instrument for achieving good governance" in developing countries because it provides a framework for organizing comprehensive e-reforms, starting with government and the public sector (Saidi \& Yared, 2002). Mehmood (2013) "refers e-government to the delivery of government information and services to the people by using the internet, intranet, the worldwide web and other latest means of ICT" (Mehmood, 2013). Hassan (2009) writes about the significance of e-governance for developing countries, especially in Bangladesh, and claims that e-governance is the solution to bad or poor governance and helps to enhance the efficiency of governments by "reducing corruption, red-tapism, bureaucratic elitism and inefficiency, favoritism, lack of accountability and transparency" (Hassan, 2009). Ahmed (2018) has conducted research about good governance in developing countries and pointed out successful practices. On the basis of her study, she suggested that "the mechanisms of egovernance are an antidote to poor governance and could play a significant role in ensuring good governance in developing countries" (Ahmed, 2018). E-governance also offers opportunities for transformations in public administration. Today, computers and the internet are considered mandatory in every government office to enhance its efficiency and performance.

\subsection{E-Governance in Pakistan}

The history of e-governance in Pakistan can be traced back to the year 2000. E-governance is changing the culture of work and function in Pakistan. It integrates various government functions and processes in order to provide better services to citizens. The Ministry of Information Technology was founded in the same year and it made sure that, from that point on, most universities and colleges had to have their own IT training and education departments to strengthen the local IT industry through 'Pakistan Export Soft Board". The training programs have various implications for organization as well as for employees (Khan \& Iqbal, 2020a, 2020b). The government of Pakistan signed MOUs with those countries that had launched e-government programs successfully, like South Korea, China, and Malaysia (UK Essays, 2018). The IT Policy and Action Plan 2000 was the first IT policy of Pakistan, in which the government paid attention to deploying IT facilities to perform the functions of the state and also admitted it as a significant tool for the sustainable 
development of the country. Later, it was aggressively embarked upon to induct information technology at all levels of government (Ilyas, 2016).

In the Ministry of Science and Technology, an Electronic-Government Directorate (EGD) was established as a unit. It was aimed at employing different correlated projects in e-government, providing guidelines to implement the e-government projects, and also assessing the available technological equipment and making recommendations to utilize them. It also set standards for the infrastructure and software in the field of e-government. Further, it assessed the requirements of the ministries and various concerned departments. In 2005, EGD prepared a document titled "EGovernment Strategy and 5 Year Plan." It was approved by the "National E-Government Council" (NEGC) and also endorsed by the Federal Cabinet. This strategy proposes to deploy the basic IT infrastructure in all government offices and agencies. It designed and developed uniform applications for various government divisions and also provided numerous e-services to the common citizens, along with setting or establishing standards for ongoing and future projects of egovernment (Pak e-government Strategy, 2005).

This plan of 2005 and the deployment of IT infrastructure actually helped to raise awareness regarding the use of e-government services among the citizens who were facilitated with better delivery services during this phase. Although the goal of e-governance projects was to increase the efficiency of government institutions, the norms of transparency, efficiency, accountability, and effectiveness were ensured in the decision-making process. Furthermore, it is certainly cost-effective along with the efficient delivery services for its citizens because, gradually, the cost of technology has decreased. According to an official report of the Pakistan Telecommunication Authority in 2010, "teledensity had reached $65.4 \%$ and at the end of 2010, the growth of broadband was outstanding at over $100 \%$ from the previous year 2008-09" (IEEE, 2010).

For the strengthening of good governance through e-governance structures, the Ministry of IT in Pakistan arranged an "E-Office Forum-2014" in May 2014. It had the slogan "e-governance for good governance". The basic purpose behind the establishment of that forum was "to share the experiences regarding the e-governance initiative of the e-office/e-filing system to sensitize all the stakeholders about its importance, and ask for their active support in its implementation and to highlight their key roles and responsibilities" (Ilyas, 2016).

The Electronic Government Directorate of Pakistan has initiated several programs at the federal as well as provincial levels. The major projects included:

National Data Warehouse, Records Digitization, Electoral Rolls, Graphical Information System, Web Archive Management, E-Archiving, Electronic Assessment System (Easy), Motor Vehicle Registration, Portal seminars, These specifically include the Federal Government Official Portal (www.pakistan.gov.pk), the Punjab Province web portal (www.punjab.gov.pk), the Sindh Province Portal (http://www.sindh.gov.pk), the Punjab Intranet, Prison Management Information Systems, Land Record Management Information Systems, Computerization of Arms Licenses, and more. Some important features of these programs are also listed here: e-complaint, crime reporting, e-file tracking, etc. Some of the above-mentioned web portals are online. Some of these are still under development but have already been approved by the Government of Pakistan (GOP) for the software development companies "(UKEssays, 2015). 
Table 1: Evolution of E-Governance in Pakistan

\begin{tabular}{|c|c|}
\hline Policy Influence Sector & Policy Name \\
\hline $\begin{array}{l}\text { Telecom-Sector } \\
\text { Governing Legislation }\end{array}$ & $\begin{array}{l}\text { Pakistan Telecommunication (Re-organization) Act } 1996 \text { (amended } \\
\text { in 2015) }\end{array}$ \\
\hline IT Sector Policies & National IT Policy 2000 \\
\hline Telecom Sector Policies & $\begin{array}{l}\text { - De-Regulation Policy for the Telecommunication Sector -2003 } \\
\text { - Mobile Cellular Policy- } 2004 \\
\text { - Broadband Policy - } 2004 \\
\text { - Universal Service Fund } \\
\text { - Policy - 2006 }\end{array}$ \\
\hline Digital Pakistan Policy & $\begin{array}{l}\text { Digital Pakistan Policy -2018 } \\
\text { - Cloud Computing and Big Data } \\
\text { - IoT, Artificial Intelligence \& Robotics } \\
\text { - ICT Education } \\
\text { - E-Justice } \\
\text { - E-Commerce } \\
\text { - E-health } \\
\text { - E-Agriculture }\end{array}$ \\
\hline $\begin{array}{l}\text { Smart Village Project } \\
2021\end{array}$ & $\begin{array}{l}\text { Ministry of IT and Telecommunication through Universal Service } \\
\text { Fund launched a "Smart Village" project in four provinces, Islamabad } \\
\text { and Gilgit-Baltistan. Under the project, a center to be set up in a } \\
\text { backward village equipped with modern facilities from which not only } \\
\text { the people of the area will be trained to use IT facilities but also they } \\
\text { will be encouraged to incorporate it in their daily life. }\end{array}$ \\
\hline
\end{tabular}

Source:https://www.itu.int/en/ITU-D/Regional-

Presence/AsiaPacific/SiteAssets/Pages/Events/2019/

\subsection{Progress in E-Governance during the Current Government Regime}

The current government of PTI has worked progressively on its vision of "Digital Pakistan" to ensure good governance. The Prime Minister's emphasis is more on the implementation of the programs of e-governance to ensure transparency in the governmental processes and activities. The sudden outbreak of the COVID-19 pandemic has also escalated the urge to use electronic media to govern state affairs and the public service sector. Pakistan is currently using ICT to be engaged in Sectoral Digitalization, Standardization, Infrastructure Development, Women's Development, Human Resource Development, Encourage Innovation, Local Hardware Manufacturing, R \& D, Increase Software Exports, Software Technology Parks, E-governance, Legislation (Khan, 2018).

As a result of persistent and promising IT development in Pakistan, up-till 2018, Pakistan has 1500 registered companies, among which 2 are listed on the KSE and 2 on the NASDAQ (stock exchange related), and 1 is listed on DFIX (IT). 9 STPs (IT) offered 700,000 sq ft of IT-enabled office space, 70 foreign IT \& $\mathrm{T}$ companies, a skilled workforce of 110,0oo English-speaking IT professionals, among which 24,000 are engaged in exports, seven multinational companies have their "Development Centers" in Pakistan, and a strong telecom sector has been established to support IT industry development (Khan, 2018). In 2019, Pakistan's e-commerce policy mainly focused on "regulatory facilitation framework, financial inclusion and digitization through payment infrastructure, empowerment of youth and SMEs through e-commerce, taxation issues, consumer 
protection in the digital environment, ICT e-commerce, data ownership/sovereignty, and data localization" (MoC\&T, 2019). Further, the government of Pakistan is working on progressive policies (that are in the consultation phase) for the benefit of the common people. National Broadband Policy 2021, National Cyber Security Policy 2021, and National Freelancing Facilitation Policy's consultation draughts have been prepared, and soon people will benefit from them.

\section{Table 2: E-Governance Initiatives in Pakistan}

E-Governance Initiatives in Services Sector

- Khidmat Markaz (integrated 17 governmental services to citizens like birth, marriage, divorce, character, death certificates, NADRA e-sahulat, route permit etc.)

- Baytee App (this app was introduced for the 51\% population of Pakistan to feel secure and empowered through technology)

- Mera Bacha App (this app linked with a special Integrated Response Mechanism (IRM) to efficiently handle the cases of child sexual abuse and abduction)

- Pass Track App (it records and tracks the information of foreign passengers \& travelers in Pakistan by scanning the National Identity Card and Passport of Pakistan.

- Durust Daam App (it enables the citizens of Pakistan to confirm updated prices of essential commodities and to lodge complaints against the market monopolists.

- Clean and Green Pakistan (this app is used to report unhygienic and dirty washrooms at Petrol Stations to the local administration)

- City Islamabad App (this app offers public services, features, and tools like e-Police, excise and taxation, CDA, e-NADRA, notifications, city guide, utility bills, and other valuable services)

- Case Tracking System (it helps the law officers to get registered across the nation, to know the governments cases, and to get alerts through e-mail before the date of hearing)

- Central Collaborative System (it provides information about the existing developed software to focus on new software to save efforts, time, and HR)

E-Governance Initiatives for Socio-Economic Development

- Board of Investment Visa Portal (it facilitates the entire business community with overall visa applications through the online portal)

- Economic Affairs Division (EAD) NGO Portal (a smart online portal for the registration and database management of related activities i.e., external economic assistance and also to assess the requirements)

- Kamyab Jawan Program (aims at uplifting the youth's morale and enhancing their entrepreneurial potentials by providing them loan opportunities to contribute to the economic growth of the country)

- Freelancer Facilitation Hub (FFH) (provides online data of available freelancers in Pakistan to strengthen the 'knowledge economy' by utilizing their skills and expertise)

- Ehsaas Program (a program of social safety and poverty alleviation to make Pakistan a welfare state, it includes, Ehsaas National Socio-Economic Registry, Ehsaas Kafaalat Program, Ehsaas Emergency Cash, PM's COVID-19 Fund Portal, Ehsaas Rashan Portal, IT hubs and incubators in 450 BISP offices, Ehsaas Nashonuma, Undergraduate Student Scholarships, Education CCT, Ehsaas Amdan Program, Graduation and interest-free loans, Data4Pakistan Portal, Ehsaas TV, One Window Ehsaas App, Tahafuz, pledges to Ehsaas, Langar, Food Card, Garbage Rickshaw, online education, Artisans to Fashion Houses, platforms for daily-wage workers, etc.)

- National Jobs Portal (it is a single platform for the job seekers to get hired at their desired jobs 
on the pure merit basis to maintain transparency)

E-Governance Initiatives in Health Sector

- WECARE (it helped to protect the frontline health workers dealing with the patients of COVID-19 and also sensitize the public to reduce the infections through health providers.

- Central Information Board (it gave detailed and clear information about the allocated, released, and disbursed amount of COVID relief fund across cities)

- Pak-Nigehban- National Emergency Response (this app helps to locate the nearest hospitals, labs, beds, or ventilators for the corona patients)

- CORONA Relief Tigers Registration (integrated with Citizens' Portal and allowed the citizens to register themselves as a volunteer)

- COVID-19 Mobile Platform (it gave the latest and legitimate information related the coronavirus cases in the country.

- Naya-Pakistan Qoumi Sehat Card App (the Punjab government launched this app to provide information on the 'Sehat Sahulat Program'. It provided financial assistance of one million for the treatment in various public and private hospitals, free counseling, and health insurance to the cardholders).

E-Governance Initiatives in Financial Sector

- Raast App (Pakistan's Instant Payment System that enables end-to-end digital and instant payments among individuals, businesses, and government entities)

- Online Mobile Banking (this app designed to simplify the banking experience of their customers and also enable them to access and transact through their account anywhere and anytime)

- FBR E-payments (Federal Bureau of Revenue facilitates e-payments to pay the income tax, land tax, and customs duty, etc.)

- Roshan Digital Account (State Bank of Pakistan with the collaboration of operating commercial banks in Pakistan gave banking solutions (regarding investments and payments) to the overseas Pakistanis.

E-Governance Initiatives to enhance participation of the Overseas Pakistanis

- Electronic Voting Machine (On 18 Nov 2021, the government of Pakistan successfully passed the bill for using EVMs in the upcoming general elections of Pakistan. It enables almost nine million overseas Pakistanis to cast their vote in the 2023 polls.

- Call Sarzameen (it digitalized the overall process of registering complaints of overseas Pakistanis to ease and eradicate their grievances.

- Yaaran-e-Watan (connects overseas Pakistani health providers/professionals with professional volunteering opportunities in Pakistan to upgrade the Clinical, Non-Clinical, and Pharmacy sector of Pakistan.

Source: developed by the author, data are derived from BOI, FBR, commerce.gov.pk, invest.pk, sbp.org.pk, aboutpakistan.com, psw.gov.pk, nbdp.org.p

\subsection{E-governance initiatives to Ensure Good Governance}

Pakistan has initiated and followed numerous e-governance programs to strengthen good governance. For sustainable socio-economic development, Pakistan needs significant improvements in its ICT policies. The given below table is describing the programs and their purpose of initiation for a better understanding of the e-facilities provided by the government. In this regard "National Digital Pakistan Policy" remarkably performs in the various sectors of the government to provide better e-governance services to the common citizens to strengthen the G2C, G2B, and G2G link. The following table identified different initiatives of the Prime Minister of Pakistan Imran Khan to ensure 
compliance with the norms of good governance and also helps to understand in which areas there is still a need to improve and introduce reforms.

Table 3: Initiated Programs to ensure Good Governance through E-Governance

\begin{tabular}{|c|c|c|}
\hline \multicolumn{3}{|c|}{ To Ensure Participation, Equity \& Inclusiveness, Accountability \& Transparency } \\
\hline G2G & G2B & G2C \\
\hline $\begin{array}{l}\text { E-enablement of the Federal } \\
\text { Investigation Agency (FIA) } \\
\text { ensures the maximum } \\
\text { connectivity of the government } \\
\text { offices through the internet } \\
\text { and restrain the use of illegal } \\
\text { and unlicensed software. }\end{array}$ & $\begin{array}{l}\text { Board of Investment Visa } \\
\text { Portal receives, accepts, } \\
\text { scrutinizes, and issue visa } \\
\text { applications of the entire } \\
\text { business community. }\end{array}$ & $\begin{array}{l}\text { Monitorization } \\
\text { Maintenance of PM Citizen } \\
\text { Portal bridge the } \\
\text { communication gap between } \\
\text { the citizens and the } \\
\text { government. }\end{array}$ \\
\hline $\begin{array}{l}\text { Prime Minister's Office } \\
\text { Computerization was decided } \\
\text { to improve the internal } \\
\text { communications and functions } \\
\text { of the government through } \\
\text { automation of the different } \\
\text { wings. }\end{array}$ & $\begin{array}{l}\begin{array}{l}\text { Office of the Attorney } \\
\text { General for Pakistan } \\
\text { (Computerization }\end{array} \\
\text { Execution of Government } \\
\text { Cases) The 'Case Tracking } \\
\text { System' (CTS) helps the law } \\
\text { officers to get registered } \\
\text { across the nation, to know the } \\
\text { government cases, and get } \\
\text { alerts about the hearing date. }\end{array}$ & $\begin{array}{l}\text { The Monitoring and } \\
\text { Evaluation System (M\&ES) } \\
\text { helped the government to } \\
\text { perform its routine services } \\
\text { efficiently by improving the } \\
\text { norms of flexibility, reliability, } \\
\text { scalability, uninterrupted } \\
\text { communication, enhanced } \\
\text { accessibility, and security to } \\
\text { the citizens. }\end{array}$ \\
\hline $\begin{array}{l}\text { E-office app introduced to } \\
\text { establish paperless } \\
\text { administration in the } \\
\text { government offices }\end{array}$ & $\begin{array}{l}\text { Ease of doing Business } \\
\text { Portal: many measures } \\
\text { introduced for the facilitation } \\
\text { of e-commerce, like } \\
\text { Registration of companies, } \\
\text { getting online information, } \\
\text { online complaint portal, online } \\
\text { comparing, airport entry pass, } \\
\text { petroleum companies' } \\
\text { clearance, online tax payment } \\
\text { etc. }\end{array}$ & $\begin{array}{l}\text { Overseas Pakistani: the } \\
\text { government following } \\
\text { initiatives ensures the } \\
\text { participation of the overseas } \\
\text { Pakistanis in state affairs, like } \\
\text { online voting through EVM, } \\
\text { Call Sarzameen, Yaaran-e- } \\
\text { Watan, }\end{array}$ \\
\hline
\end{tabular}




\begin{tabular}{|c|c|c|}
\hline $\begin{array}{l}\text { Mobile App for Wafaqi } \\
\text { Mohtasib facilitated almost } \\
7000 \text { government employees } \\
\text { and increases work efficiency } \\
\text { by rapid response and non- } \\
\text { delay in the maintenance and } \\
\text { handling of the organizational } \\
\text { affairs. }\end{array}$ & $\begin{array}{l}\text { Economic Affairs Division } \\
\text { (EAD) NGO Portal developed } \\
\text { for the registration and } \\
\text { database management of all } \\
\text { the related activities that } \\
\text { include the assessment of } \\
\text { requirements and external } \\
\text { economic assistance from the } \\
\text { government, constituent units, } \\
\text { foreign governments, and } \\
\text { multilateral agencies. }\end{array}$ & $\begin{array}{l}\text { Durust Daam App confirms } \\
\text { the current and updated prices } \\
\text { of essential commodities and } \\
\text { allows to lodge complaints } \\
\text { against the monopolists in the } \\
\text { market. }\end{array}$ \\
\hline $\begin{array}{l}\text { Central Information } \\
\text { Dashboard gives a clear } \\
\text { reflection of allocated, } \\
\text { released, and disbursed } \\
\text { amounts of the PM COVID } \\
\text { relief fund and also provide } \\
\text { help to the ministries to track } \\
\text { and record real-time disbursed } \\
\text { amounts across cities. }\end{array}$ & $\begin{array}{l}\text { Pakistan Single Window is } \\
\text { launched to reduce the time } \\
\text { and cost of doing business by } \\
\text { digitalizing Pakistan in trade } \\
\text { and related government } \\
\text { services. PSW explains } \\
\text { Pakistan's policies and } \\
\text { government policies and acts } \\
\text { in detail. }\end{array}$ & $\begin{array}{l}\text { WECARE was launched to } \\
\text { protect the frontline health } \\
\text { workers while dealing with } \\
\text { COVID-19. It aimed to sensitize } \\
\text { the public to reduce the risks } \\
\text { of infection. } \\
\text { COVID-19 Mobile Platform } \\
\text { updated the latest and } \\
\text { legitimate information related } \\
\text { to Corona cases in Pakistan. } \\
\text { Pak Nigehban Emergency } \\
\text { Response (to locate nearest } \\
\text { hospitals and labs to test and } \\
\text { treat coronavirus) } \\
\text { CoRONA Relief Tigers' } \\
\text { Registration (for citizens' } \\
\text { who voluntarily wanted to } \\
\text { participate in Tiger force) }\end{array}$ \\
\hline
\end{tabular}

Source: developed by the author, data is derived from various official websites of government of Pakistan

In short, e-governance in Pakistan is rapidly growing and the indexes of internet and mobile usage have also been rising continuously, especially since the last decade. However, it is still an emerging sector despite a perceptible surge in online marketing, vendors, local e-Commerce platforms, and online payment facilities introduced by various banks and large cellular companies. In fact, "Pakistan has become a leader in mobile banking transactions in South Asia" (MoC \& T, 2019). The formulation of the "Digital Pakistan Policy 2021" is a remarkable step in fulfilling the vision of the government to transform Pakistan's image as a digitally developed country. The policy covers the key components for the promotion of e-commerce, including the regulatory environment, financial inclusion and digitization through payment infrastructure, empowering youth and SMEs, consumer 
protection, taxation, ICT infrastructure, logistics, data sovereignty and engagement in multilateral negotiations (MoC and T, 2019). Due to the developments and initiatives of ICT technology and the " $4^{\text {th }}$ Industrial Revolution", Pakistan is progressing towards a more connected world through digital transformation. Therefore, increased connectivity also enhances the sharing of information and data on web portals.

The various e-government services (like banking, payments, and transactions) that contain sensitive information about individuals, businesses, and governments are interconnected now and have become prone to malicious use like hacking, procurement, and online fraud, etc. Despite the fact that Pakistan has cyber security policies, those policies do not provide an effective "Cyber Security Mechanism. "Pakistan Telecommunication (Re-organization) Act 1996, Electronic Transaction Ordinance 2002 that (only covered the electronic financial transactions and records), investigation for Fair Trial Act (IFTA)-2013 and Prevention of Electronic Crime Act (PECA)-2016 covers some of the aspects of information and cyber security. Although in 2018, the National Centre for Cyber Security was established for academic research, Pakistan still lacks IT skills and expertise, and therefore, much of the hardware and software is imported from IT expert countries. "This reliance, along with the absence of national security standards and weak accreditation, has made Pakistan vulnerable to foreign exploitation through embedded malware, backdoors, and chipsets" (MoITT, 2021). However, the government of Pakistan worked hard and consistently to establish a governance and institutional framework for a secure cyber ecosystem and finally presented the "National Cyber Security Policy-2021" to protect the cyberspace of Pakistan.

\subsection{Challenges of E-governance in Pakistan}

Although this digital transformation has numerous benefits, the implementation has not yet resulted as expected. This is due to the various challenges that governments are facing at different levels. Initially, the issues associated with this digital transformation in Pakistan were related to the required infrastructure and a lack of funds in the implementation of the E-governance structure. Almost all the developing countries at that time were lacking the finances to buy the necessary infrastructure to implement e-governance transformation. The ICT infrastructure and architecture in place were necessary to establish an effective and uniform set of principles and standards for the whole department to work efficiently. Therefore, the government of Pakistan decided to utilize the existing institutions (colleges and universities) and focused on the deployment of infrastructure only. Another serious challenge that is of global nature is a breach of privacy and security. The issues regarding hacking, tracking, and misuse of personal information were the biggest challenges. By that time, the use of firewall protection and limitations on the access of confidential information had reduced the concerns. However, the use of firewalls, some security technologies like encryption, and digital signatures to protect the E-infrastructure helps to reduce the concerns. Most developing countries and their human resources are lacking in the field of digital skills (Rasool et al., 2021). For the proper functioning and desired results, proper training is mandatory (Junaid, Bashir, Nasim, \& Ahmad, 2021; Khan, Bhatti, Hussain, Ahmad, \& Iqbal, 2021). It is essential for governments to take appropriate steps to evoke the technical and functional skills of their citizens.

Pakistan, like many other developing countries, lacked computer literacy, and therefore fewer people knew about digital availability through the internet. Further, the internet skills of the individuals are not equal, so their access capability to the internet is also varied. Further, internet availability is another serious issue in the way of connectivity. Therefore, all the people/citizens having access to the internet at a single time seems impossible. Pakistan's Ministry of IT \& 
Telecommunication explained its mission statement in these words; "Improve Pakistani citizens' quality of life and economic wellbeing by ensuring the availability of accessible, affordable, reliable, universal, and high-quality ICT services" (Khan, 2018). And the experts in e-governance said that: "The digital transformation of e-governance has the potential to administrate systematically." It is a tool used to run a government for the benefit of its citizens. The services can be provided to citizens on time and on demand. The criminal cases registered in police stations cannot be manipulated if the files are digital. The digital transformation in the public sector will be a boon to the country if it is successful "(enterprisetouch, 2019). Despite numerous challenges in the implementation of digital policies in Pakistan, governments have remained committed to the development of the country's IT sector. So, we investigated many policies regarding the establishment and development of the IT sector in Pakistan that actually helped in achieving this goal of "Digital Pakistan".

\section{Methodology}

An exploratory and descriptive method are used under a qualitative approach to investigate the progress of e-governance and its potential relationship with good governance in Pakistan. Primary and secondary sources are used to collect the data. However, primary data is collected through various official websites of the government.

\section{Conclusion}

Pakistan's E-governance system is aged 22 only, but in this period, the implementation of ICT in the various government sectors is remarkable. It is rightly said that politics and government are to provide services to the people, and e-governance made it easy for governments to provide more services to more people and enabled the common people to get more facilities from the government. It is anticipated at the end of the study that the benefits of e-governance will be increased with the passage of time, and the citizens' will be facilitated more by:

1. Granting easy and rapid access to the required information not only for citizens but for the business sector as well. It will enhance citizens's participation, efficiency, transparency, and accountability in different sectors of society.

2. The participation of the general public will be increased at all levels of government in order to strengthen Pakistan's participatory democracy.

3. It will help the public in decision-making as well when information about government activities is easy to access and also benefits the government by increasing the level of outreach to the beneficiaries.

4. The facilities for public welfare will be available to all citizens at the right time. It will reduce the chances of corruption.

5. All the government's activities and dealings will be more transparent, reducing the extra costs that citizens pay to complete their tasks.

6. The efforts and time of citizens will be reduced when all their work is done smartly. It enhances the citizens' empowerment capacity.

7. Smart and close monitoring of the institutions will also help to reduce malpractices.

8. The performance of the institutions and individuals will also be closely monitored and it will be easy to find the grey areas.

9. Public contact and trust will increase because the services of middlemen and bribery will be eliminated in their dealings with officials.

10. Governments become close to the general public and can seek knowledge about the public demands that will help the government improve key areas. 


\section{Recommendations}

Despite numerous challenges in the implementation of digital policies in Pakistan, governments have remained committed to the development of the country's IT sector. However, the government should ensure the availability of accessible, affordable, reliable, universal, and highquality ICT services. The government should extend IT literacy to remote areas too. The DRC system must be foolproof and available to every government office to avoid damage to digital office records.

\section{References}

Ahmed, B. (2018). The Linkage Betwen E-Governance and Good Governance: An Analysis on

Bangladesh Public Administration. Humanities and Social Sciences, 114-120.

Atta Ullah, C. P. (2021). "The Role of E Governance in Combating COVID 19 and Promoting Sustainable Development: A Comparative STudy of China and Pakistan". Chinese Political Science Review, 86-118.

enterprisetouch. (2019, February 15). What is the Role, Importance and Challenges for e-governance Transformation? Retrieved July 04, 2021, from Enterprisetouch: https://www.enterprisetouch.com/what-is-the-role-importance-and-challenges-for-egovernance/

Hassan, S. (2009). Introducing E-Government in Bangladesh: Problems and Prospects. International Social Sciences Review , 111-125.

IEEE. (2010). Factors influencing e-Governance implementation: Issues and Challenges in Pakistan. 'Digital Information Management (ICDIM) (p. 120). Fifth International Conference.

Ilyas, M. (2016). "E-Governance Practices and Models; Options for Pakistan". ISSRA Papers, 43-64.

Izhar Ud Din \& Xue, M. C. (2017). "Role of Information \& Communication Technology (ICT) and egovernance in health sector of Pakistan: A case Study of Peshahwar". Cogent Social Sciences, 1-18.

Javeria, A., Rizwan, M., Khan, A., Hameed, A., Neem, Q., \& Subctageen, M. (2013). Examining the Antecedents of Job Satisfaction and further its impact on Organizational Commitment. Journal of Public Administration and Governance, 3(3), 317-334.

Junaid, A., Bashir, F., Nasim, I., \& Ahmad, R. (2021). Understanding Affective, Normative \& Continuance Commitment through the Lens of Training \& Development. iRASD Journal of Management, 3(2), 105-113.

Khan, A. J., Bhatti, M. A., Hussain, A., Ahmad, R., \& Iqbal, J. (2021). Employee Job Satisfaction in Higher Educational Institutes: A Review of Theories. Journal of South Asian Studies, 9(3).

Khan, S. A. (2018, October 30). "IT Policies \& Projects in Pakistan". Retrieved July 05, 2021, from ITU: https://www.itu.int/en/ITU-D/RegionalPresence/AsiaPacific/SiteAssets/Pages/Events/2019/jul-iran-dtx/Workshop-on$\%$ E2\%80\%9CDigital-Transformation-in-DigitalEconomy\%E2\%80\%9D/Session\%2011_ITU-Iran-Salman-Khan_Pakistan.pdf

Khan, A. J., \& Iqbal, J. (2020a). Do High Performance Work Practices Increase the Organizational Performance of Public Sector Companies? An Investigation of Mediation Mechanism. Pakistan Journal of Social Sciences (PJSS), 40(2), 1007-1021.

Khan, A. J., \& Iqbal, J. (2020b). Training and Employee Commitment: The Social Exchange Perspective. Journal of Management Sciences, 7(1), 88-10o.

Mehmood, Z. (2013). Developing E-Government Projects: Frameworks and Methodologies. USA: IGI Global .

MoC\&T. (2019). E-COMMERCE POLICY: FRAMEWORK OF PAKISTAN. Pakistan: Ministry of 
Commerce \& Textile, Government of Pakistan.

MoITT. (2021). NATIONAL CYBER SECURITY POLICY 2021. Pakistan: Government of Pakistan. Pak e-governemnt Strategy. (2005). 'E-Government Strategic Plan For The Federal Government'.

Rasool, Z., Asghar, R., Gill, S. A., \& Khan, A. J. (2021). The Historical Role of Work Social Support, Corporate Social Responsibility (CSR) and Innovation Capabilities. PERENNIAL JOURNAL OF HISTORY, 2(2), 331-352.

Saidi \& Yared, N. S. (2002). eGovernment: Technology for Good Governance, Development and Democracy in the MENA Countries. Mediterranean Development Forum IV, 1-25.

Singh, H. (2017, Aug 17). "What is the difference between E-government and E-governance". Retrieved July 2, 2021, from Jagran Josh: https://www.jagranjosh.com/generalknowledge/what-is-the-difference-between-egovernment-and-egovernance-1503018565-1

UKEssays. ( 2018, November). The E Government Initiatives In Pakistan Information Technology Essay. Retrieved July 04, 2021, from UKEssays: https://www.ukessays.com/essays/information-technology/the-e-government-initiatives-inpakistan-information-technology-essay.php?vref $=1$

UKEssays. (2015, Jan 01). The E Government Initiatives In Pakistan Information Technology Essay. Retrieved July 04, 2021, from UKEssays: https://www.ukessays.com/essays/informationtechnology/the-e-government-initiatives-in-pakistan-information-technologyessay.php\# citethis

UN. (2003). World Public Sector Report 2003: E-Government at the Crossroads. New York: UN Publications.

Wikipedia. (2021, Nov 02). E-Governance. Retrieved from Wikipedia: https://en.wikipedia.org/wiki/E-governance 